\title{
Annual Operating Cost for Multiple Machines versus Single Machine
}

\author{
Hasan Seyyedhasani* \\ Department of Biosystems and Agricultural Engineering, University of Kentucky, USA
}

Submission: February 21, 2017; Published: March 03, 2017

"Corresponding author: Hasan Seyyedhasani, Department of Biosystems and Agricultural Engineering, University of Kentucky, 128 CE Barnhart Building, Lexington, KY 40546-0276, USA, Email:hshasaniT@uky.edu

\section{Introduction}

Reducing field completion times in agricultural operations is of paramount importance. Some direct impacts of this consideration are the following:

a. Enabling producers to quickly move equipment to the next field and work more acres in limited timeframes.

b. Mitigating unforgiving effects of weather and severe profit penalties due to missing the optimal times to perform field operations.

c. Minimizing temporal differences between crop states in the same field, which is especially important in operations such as planting, swathing, or baling.

Agricultural machinery manufacturers over the decades have been doing their best to tackle these issues. Often, their approach has been increasing size and horsepower of the equipment.

Larger and heavier machines, however, are not the perfect solution for the problem, as there are debates about compacting the soil structure. Soil structure is important because it is the primary parameter in holding and conducting water, air, and nutrients necessary for plant root, thereby affecting the field yield. Additionally, there are growing concerns among farmers about different aspects. First, if equipment breaks down (even for a couple of hours), it would be costly for them. Second, larger and cumbersome equipment isn't flexible for fields that often have convoluted shape and are sometimes small. There is a viable solution of using multiple machines. This approach allows the use of smaller machines which have less compaction risk. It also provides redundancy in the event of an equipment failure and more flexibility in travelling around the fields. However, the higher annual cost is the main issue associated with deploying multiple smaller vehicles.

Farm machinery costs can be divided into two major categories: ownership costs, and operating costs. The annual ownership cost occurs regardless of machine use, whereas the annual operating cost varies directly with respect to the amount of machine use. However, the true value of these costs cannot be known until the machine is sold or worn out. This doesn't mean these costs cannot be estimated. The costs can be predicted by making a few assumptions about the main costs of having equipment such as the amount of operation, repair and maintenance, fuel consumption, lubrication, and labor prices happened per year.

Ownership costs, also called fixed costs, include depreciation, interest, taxes, insurance, and housing and maintenance facilities. Operating costs, also called variable costs, include repairs and maintenance, fuel, lubrication, and operator labor. In this context, the annual operating costs will be discussed. In addition, in order to have a better understating of these estimated costs, the annual operating cost for three smaller tractors is investigated versus a single big one. Two different tractors are considered for this investigation: a small one which is capable of producing $145 \mathrm{hp}$, and big one approximately three times as powerful as the small one which is $420 \mathrm{hp}$ powerful. These machines are available in the list of products of John Deere Company.

\section{Repairs and Maintenance}

Repair costs occur because of routine maintenance, wear and tear, and accidents. Repair costs for a particular type of machine vary widely from one geographic region to another because of soil type, rocks, terrain, climate, and other conditions. Within a local area, repair costs even vary from a farm to another farm because of different management policies and operator skill. The accumulated repair cost can be calculated through the following equation (American Society of Agricultural and Biological Engineers, 2015).

Accumulated Repair Cost $=$ NEP $\mathrm{x}$ RF1 $\mathrm{x}$ (Accumulated Hours $(1000)^{\wedge} \mathrm{RF} 2$ 
Where NEP is new equivalent price of a machine, RF1 and RF2 are repair factors. According to the American Society of Agricultural and Biological Engineers (2015), the RF1 factors hold be 0.007 for two wheel drives and 0.003 for four wheel drives and crawler tractors.RF2 is 2.0 for all three tractor classes.

Therefore, assuming annual working hours of 400 for tractors, the annual repair cost for the tractors of $145 \mathrm{hp}$ and 420 hp will be equal to $\$ 169.06$ and $\$ 399.9$, respectively. Considering the fact that the big tractor can be replaced with three smaller ones to garner the advantages of utilizing multiple tractors on the farm to perform the same task, it is possible to multiply the repair costs of the small tractor by three which accounts for $\$ 507.18$. This indicates that deploying multiple machines to perform a specific operation will cost $26.8 \%$ more than having a single big machine, in terms of repair and maintenance.

\section{Fuel Consumption}

Fuel consumption should be another consideration in comparison of single machine with multiple ones. Consumption of an additional one gallon of fuel per hour cost a lot over a longer period of time. The higher the power of a machine is, the more fuel will be consumed by the machine per hour. This, however, makes the machine to complete more work during the same amount of time. As such the fuel cost can bring back to the same cost per work done. Average fuel consumption, in gallons per hour, for farm tractors on a year-round basis without reference to any specific implement can also be estimated with the equation as follows [1]:

Average fuel consumption $=0.044 \mathrm{x}$ maximum PTO horsepower for diesel engines

Thus for the representative machines utilized in this investigation, fuel consumption is as below:

Average fuel consumption_420hp $=0.044 \times 420 \mathrm{hp}=18.48$ gallons/hour

Average fuel cost_420hp $=18.48$ gallons/hour $x \$ 2.4 /$ gallon $=\$ 44.35 /$ hour

Average fuel consumption_145hp $=0.044$ x $145 \mathrm{hp}=18.48$ gallons/hour

Average fuel cost_145hp $=6.38$ gallons $/$ hour $\times \$ 2.4 /$ gallon $=$ $\$ 15.312$ /hour

Therefore, the fuel consumption for multiple machines will be $\$ 45.936 /$ hour which is approximately $3.5 \%$ more than the fuel cost for a single big machine.

\section{Lubrication}

Lubrication is a vital service to lengthen the life of a agricultural machinery and prevent from furthered repair costs. Surveys indicate that total lubrication costs on most farms average about 15 percent of fuel costs [1]. Therefore, once the fuel cost per hour has been estimated, it is just needed to multiply it by 0.15 to estimate total lubrication costs. Thus for the machines used as example in this context the lubrication cost can be determined as following:

Average lubrication costs_single machine $=\$ 44.35 \times 0.15=$ $\$ 6.65$ /hour

Average lubrication costs_multiple machines $=\$ 45.936 \mathrm{x}$ $0.15=\$ 6.89 /$ hour

As with the fuel cost, estimated cost of lubrication for multiple machine is approximately $3.6 \%$ more a single big machine annually.

\section{Labor}

Typically, one operator is required for each machine in agricultural operations. Hence, there is a one to one ratio of human operators to number of machines when utilizing multiples machines on farm [2]. The capability of one human to manage and monitor multiple unmanned agricultural machines (or robots) may prove to be the most efficient way of utilizing technology to improve farm productivity. Advances in agricultural robots make the scenario of deployment of multiple robots possible. Agricultural robots which are efficient, profitable, and scale neutral will result in a situation where farm operators only monitor field operations and responds to machine errors and failures [3]. This is a crystal clear benefit of using multiple machines. However, in this context non-autonomous machines are under review and the labor cost should be taken into consideration carefully. Hence, Different number of machines requires different quantities of labor to accomplish tasks such as planting or harvesting. As such, it is important to take into account the labor costs in the analysis of machinery cost.

Actual hours of labor work usually exceed the machine work time up to 10 to 20 percent. This is due to the time required to travel around in order for lubrication and service machines. Consequently, labor costs can be estimated by multiplying the labor wage rate times 1.1 or 1.2 .

Considering the labor wage per hour of 16.22 [2]. Labor cost is can be calculated as below:

Labor cost_single machine $=\$ 16.22 \times 1.15=\$ 18.653$

Labor cost_multiple machines $=\$ 16.22 \times 1.15 \times 3=\$ 55.959$

As calculations show utilizing three smaller machines will cost $200 \%$ more than using a single big machine which is because each vehicle needs a driver.

\section{Total Annual Operating Cost}

In order to determine the annual operating cost, the partial costs of operation should be added. There for the costs calculated in for as the repair and maintenance, fuel consumption, lubrication and labor were considered to estimate the total annual operating cost. As the annual operating hours for tractors was assumed to be 400 hours, there for the total annual operating cost for a 
single big machine and multiple machines were determined to be $\$ 28245.9$ and $\$ 44021.2$, respectively. As demonstrated the total annual operating cost for deployment of three smaller machines (145-hp tractor) to perform a task simultaneously costs $\$ 15775$ more than utilizing a single big machine (420-hp tractor). This extra cost approximately $55.8 \%$ more than the cost of a single big machine. As calculations demonstrate the labor cost is the most important factor which increases the cost of deploying multiple smaller machines instead of a single big machine. In conclusion, even though three smaller machines were deployed the total annual cost didn't increase three times as much as the cost of a single big machine. Further investigations are required as to determination of the profit losses due to probable breakage, in

This work is licensed under Creative Commons Attribution 4.0 License DOI: $10.19080 /$ ARTOAJ.2017.04.555643 case of utilizing a single big machine, as well as negative impacts of soil compaction on a field yield over a long period of time. Then it would be more straight forward for farm managers to decide in regard to which approach they should adopt to increase their profit through reduction of field completion time.

\section{References}

1. Edwards WM (2001) Estimating farm machinery costs. Lowa State University, Ag Decision Maker, USA.

2. Fayer SD (2014) Agriculture: occupational employment and wages. Buearu of Labor Statistics, USA.

3. Sørensen CG, Bochtis DD (2010) Conceptual model of fleet management in agriculture. Biosystems Engineering 105(1): 41-50.

\section{Your next submission with Juniper Publishers will reach you the below assets}

- Quality Editorial service

- Swift Peer Review

- Reprints availability

- E-prints Service

- Manuscript Podcast for convenient understanding

- Global attainment for your research

- Manuscript accessibility in different formats ( Pdf, E-pub, Full Text, Audio)

- Unceasing customer service

Track the below URL for one-step submission https://juniperpublishers.com/online-submission.php 